\title{
Techniques indiennes et apports espagnols d'après les relations géographiques du Michoacan
} 1579-1582

Sylvie Lecoin et Nicole Percheron

\author{
(2) OpenEdition \\ Journals \\ Édition électronique \\ URL : https://journals.openedition.org/tc/820 \\ DOI : $10.4000 /$ tc. 820 \\ ISSN : 1952-420X \\ Éditeur \\ Éditions de l'EHESS
}

Édition imprimée

Date de publication : 1 octobre 1988

ISSN : 0248-6016

Référence électronique

Sylvie Lecoin et Nicole Percheron, «Techniques indiennes et apports espagnols d'après les relations géographiques du Michoacan 1579-1582 », Techniques \& Culture [En ligne], 11 | 1988, mis en ligne le 16 janvier 2006, consulté le 29 septembre 2022. URL : http://journals.openedition.org/tc/820 ; DOI : https://doi.org/10.4000/tc.820

Ce document a été généré automatiquement le 29 septembre 2022

Tous droits réservés 
Techniques indiennes et apports espagnols d'après les relations géographiques du Michoacan 1579-1582

Sylvie Lecoin et Nicole Percheron 